\title{
Histological and histochemical characterization of secretory cells of the male copulatory organs of Girardia anderlani (Platyhelminthes: Tricladida: Paludicola)
}

\author{
Dioneia C. da Vara $^{1} \&$ Ana M. Leal-Zanchet ${ }^{1,2}$ \\ 1 Instituto de Pesquisas de Planárias, Programa de Pós-Graduação em Biologia, Universidade do Vale do Rio dos Sinos. \\ Avenida Unisinos 950, 93022-000 São Leopoldo, Rio Grande do Sul, Brasil.E-mail: zanchet@unisinos.br \\ 2 Pesquisador do CNPq.
}

\begin{abstract}
Glands of the reproductive system are important for taxonomical identification of flatworms. We studied the histology and histochemical characteristics of the glands of the male copulatory apparatus in Girardia anderlani (Kawakatsu \& Hauser, 1983). Specimens were fixed in reproductive state, i.e. during and following copulation at four, eight, 12 and 16 hours intervals. Secretory cells were distinguished on the basis of secretion morphology and their staining properties, using trichrome methods and histochemical reactions. Twelve secretory cell types and five main types of secretions were identified in the male copulatory apparatus: glycoproteic with and without tryptophan; glycosaminoglycidic; neutral mucopolysaccharidic; and proteic. Compared to other Girardia species, more diverse types of secretory cells comprise the glands of the male reproductive system. Histophysiological comparative studies of species of Girardia, in a reproductive state, are necessary to characterize the various regions of the copulatory apparatus as well as to understand the physiology of reproduction. KEY WORDS. Dugesiidae; glands; flatworms; reproductive system.
\end{abstract}

RESUMO. Caracterização histológica e histoquímica das células secretoras dos órgãos do aparelho copulador masculino de Girardia anderlani (Platyhelminthes: Tricladida: Paludicola). Considerando a importância das glândulas do sistema reprodutor para a caracterização taxonômica de planárias, o presente trabalho objetiva fornecer uma descrição detalhada da histologia e a primeira caracterização histoquímica das glândulas do aparelho copulador masculino de Girardia anderlani (Kawakatsu \& Hauser, 1983). A análise foi realizada em espécimes fixados em período reprodutivo, i.e., durante e após a cópula (períodos de quatro, oito, 12 e 16 horas). As células secretoras foram diferenciadas com base na morfologia da secreção e em sua coloração com métodos tricrômicos e reações histoquímicas. Doze tipos de células secretoras e cinco tipos principais de secreção foram identificados no aparelho copulador masculino de G. anderlani: glicoprotéica com e sem triptofano, glicosaminoglicídica, mucopolissacarídica neutra e protéica. Em comparação com outras espécies de Girardia, verifica-se maior variedade de células secretoras constituindo as glândulas do aparelho reprodutor masculino de G. anderlani. Estudos histofisiológicos comparativos de espécies de Girardia, em período reprodutivo, são necessários para a devida caracterização das diversas regiões do aparelho copulador e compreensão da fisiologia da reprodução.

PALAVRAS-CHAVE. Dugesiidae; glândulas; planárias; sistema reprodutor.

Flatworm taxonomy is based on a combination of morphological, anatomical, and histological characters that are usually found in the epidermis, cutaneous and mesenchymal muscles, pharynx and copulatory organs. In Girardia Ball, 1974, anatomical variability frequently complicates species recognition (SLuYs 1996). After suitable fixation, detailed histological studies may provide valuable features for characterization of Girardia species (Leal-Zanchet \& Hauser 1999, Souza \& LealZANCHET 2002).

Few studies examined histology or ultrastructure of the reproductive organs of Dugesiidae Ball, 1974, being available for only five species of Girardia (Fischlschweiger \& Clausnitzer
1984, Fischlschweiger 1990, 1992, 1994, Moretto 1996, LealZaNCHET \& Hauser 1999, Souza \& LeaL-Zanchet 2002). The glands of the reproductive system of four species (Girardia festae (Borelli, 1898), Girardia bonaerensis (Moretto, 1996), Girardia schubarti (Marcus, 1946), and Girardia biapertura Sluys, 1997) were described using histochemical methods (MоREтTo 1996, Leal-Zanchet \& Hauser 1999, Souza \& Leal-Zanchet 2002). Reproductive organs of three species were studied in various reproductive phases: a resting state (precopulatory phase) as well as during and following copulation (Fischlschweiger \& Clausnitzer 1984, Fischlschweiger 1990, 1992, 1994, Moretto 1996).

Revista Brasileira de Zoologia 25 (2): 263-268, June, 2008 
Anatomy and histology of the reproductive system have been studied with taxonomical purpose in Girardia anderlani (Kawakatsu \& Hauser, 1983) (KaWAKATsu et al. 1983, 1986), but the glands of the copulatory organs have not been analyzed histologically. The analysis of glands is often hampered due to difficulties in preserving the integrity of the secretory granules (Leal-Zanchet \& Hauser 1999). Uncertainties in the physiology of anatomical, histological, and cytological components of the reproductive system have hindered taxonomic use of available characters (WINSOR 1998). Due to the importance of histological characteristics for planarian taxonomy, especially of glands of the reproductive organs (SLuys 1992, 1996, WINSOR 1998, SouZA \& LEAL-ZANCHET 2002), we provide a detailed histological analysis and the first histochemical characterization of the glands of the male copulatory system of $G$. anderlani.

\section{MATERIAL AND METHODS}

Adult specimens of $G$. anderlani were collected from Severiano de Almeida, Rio Grande do Sul, Brazil, and kept in a cold room at $20^{\circ} \mathrm{C}$. Whole worms were fixed during copulation and at four, eight, 12, and 16 hours after copulation. Fixation was performed in Lillie's 4\% neutral formaldehyde (RomeIs 1989 ) or in a variation of Karnovsky's fixative solution of $4 \%$ paraformaldehyde in $0.05 \mathrm{M}$ phosphate buffer and $4 \%$ aqueous glutaraldehyde, pH 7.2 (PlatTNeRT 1975).

Specimens fixed in neutral formaldehyde were dehydrated in an ascending ethanol series, treated with isopropanol and embedded in Paraplast (Hauser 1952). Sagittal serial sections $5 \mu \mathrm{m}$ thick were stained with Goldner's Masson, Heidenhain's AZAN or Cason's Mallory (RomeIs 1989). For better staining reactions, dewaxed sections were submitted to mordanting with SUSA's fixative (RomeIs 1989) for four hours. Some specimens were submitted to histochemical reactions for secretion identification: Alcian blue/Periodic Acid Schiff (AB/ PAS) (Romeis 1989), Bonhag's bromophenol blue (Pearse 1968),
Yasuma \& Itchikawa's Ninhydrin (Pearse 1968) and Adams's DMAB (RomeIs 1989).

Specimens fixed in paraformaldehyde/glutaraldehyde were washed in Sörensen's phosphate buffer (RUTHMANN 1966), dehydrated in an ascending ethanol series and embedded in Historesin (Reichert-Jung). Sections $2 \mu \mathrm{m}$ thick were stained with methylene blue and basic fuchsine (BENNETT et al. 1976) or toluidine blue (SPURLock et al. 1966). Measurements on the serial sections stained with trichrome methods were made by means of a calibrated eyepiece micrometer.

\section{RESULTS}

The cell body of secretory cells of the male copulatory organs of $G$. anderlani is in the mesenchyme, mainly between the penis bulb and the copulatory bursa. Ten cell types comprise the penial glands, with long cell necks that open into the bulbar cavity or into the ejaculatory duct or directly into the male atrium through the epithelium of the penis papilla (Figs 1 and 2). Two types of secretory cells open through the epithelial lining of the male atrium: one with subepithelial cell body and the second with long cell neck and cell body in the mesenchyme between the penis bulb and the copulatory bursa, as in most secretory cells.

Twelve secretory cell types and five main types of secretions (glycoprotein with and without tryptophan, glycosaminoglycans, neutral mucopolysaccharides, and protein), were identified in the male copulatory apparatus. Glycoproteic secretions are discharged into all regions of the male copulatory apparatus. Glycosaminoglycans are secreted into the bulbar cavity, ejaculatory duct and atrium through the epithelial lining of the penis papilla. Neutral mucopolysaccharidic secretions are discharged into the distal two thirds of the ejaculatory duct as well as into the atrium through the epithelial lining of the penis papilla. The atrium also receives secretion of a proteic nature.

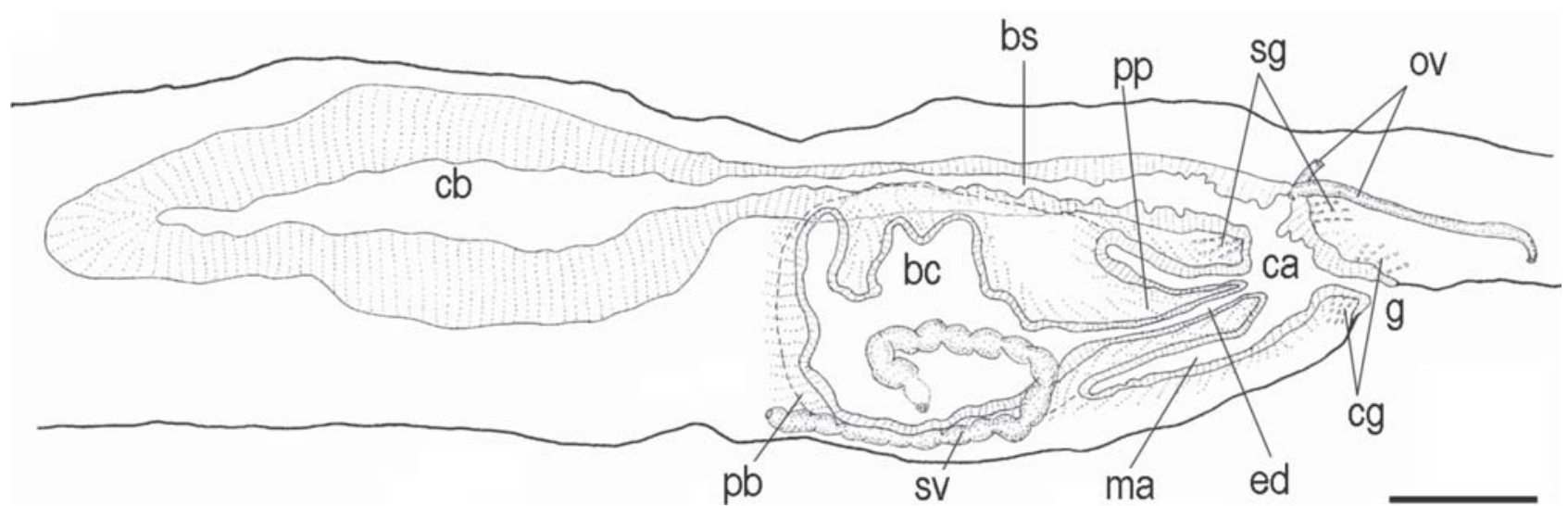

Figure 1. Schematical drawing of the copulatory apparatus of Girardia anderlani in sagittal view. Scale bar: $100 \mu \mathrm{m}$. (bc) Bulbar cavity, (bs) bursal stalk, (ca) common atrium, (cb) copulatory bursa, (cg) cement glands, (ed) ejaculatory duct, (g) gonopore, (ma) male atrium, (ov) oviducts, (pb) penis bulb, (pp) penis papilla, (sg) shell glands, (sv) false seminal vesicles.

Revista Brasileira de Zoologia 25 (2): 263-268, June, 2008 


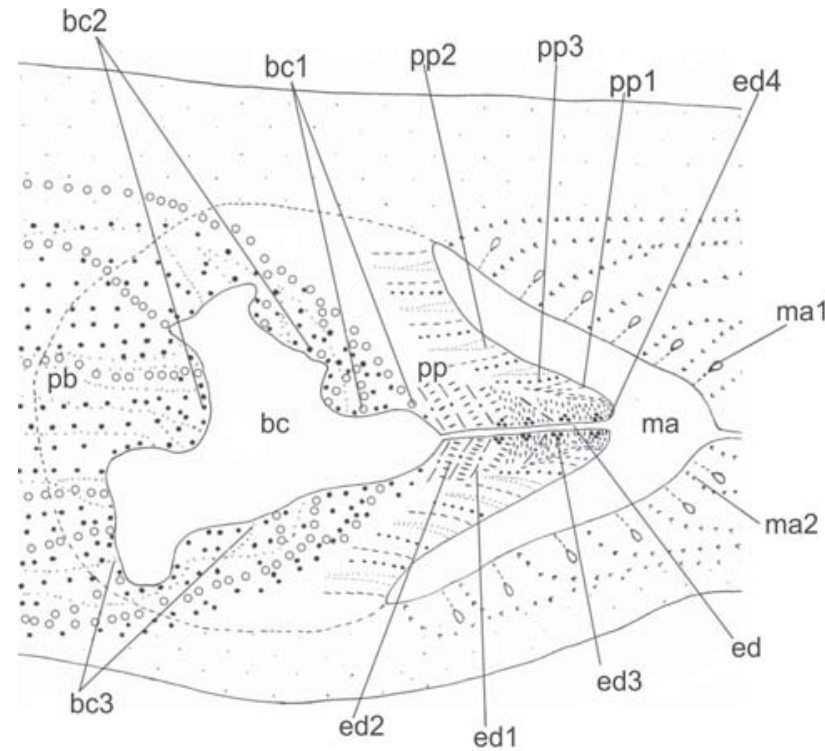

Figure 2. Diagram of the male copulatory organs of G. anderlani in sagittal view to show the openings of the different secretory cell types. (bc) Bulbar cavity, (bc1-3) secretory cells opening into the bulbar cavity, (ed) ejaculatory duct, (ed1-4) secretory cells opening into the ejaculatory duct, (ma) atrium, (ma1-2) secretory cells opening into the atrium, $(\mathrm{pb})$ penis bulb, $(\mathrm{pp})$ penis papilla, (pp1-3) secretory cells opening through the epithelial lining of the penis papilla.

The large bulbar cavity (Figs 1-3) is lined by a cuboidal or columnar epithelium (Figs 4 and 5) through which open three types of secretory cells (bc1-3). Bc1 and bc2 are abundant in the penis bulb (Figs 2 and 4-5). Bc3 opens mainly into the proximal portion of the bulbar cavity. Bc1 and bc2 have large cyanophilic secretory granules, with bc 2 granules more densely arranged in the cytoplasm. They stain similarly with trichrome methods, but reactions to AB/PAS and DMAB are quite different (Tab. I). Type bc3 is distinguished by amorphous xanthophilic secretions and staining with trichrome methods and reactions to Ninhydrin and toluidine blue. Glycosaminoglycans from type bc1 cells and glycoprotein with and without tryptophan from cell types bc2 and bc3, respectively, are secreted into the bulbar cavity (Tab. I).

The relatively short ejaculatory duct (Figs 1 and 4 ) is lined by cuboidal to squamous epithelium, with openings of four types of secretory cells (ed1-4). Openings of ed 1 and ed 2 are most abundant; openings of ed 3 and ed 4 are restricted to the distal two thirds (Figs 2, 6 and 8). Cell types ed1, ed2, and ed4 have finely granular secretions, cyanophilic in types ed1 and ed2, xanthophilic or erythrophilic in type ed4. Cell type ed3 has xanthophilic or erythrophilic amorphous secretion that stain red with toluidine blue. Cell type ed1 secretes glycosaminoglycans while cell types ed 2 and ed 3 secrete glycoproteins with and without tryptophan, and cell type ed4 secretes mucopolysaccharides into the ejaculatory duct (Tab. I).

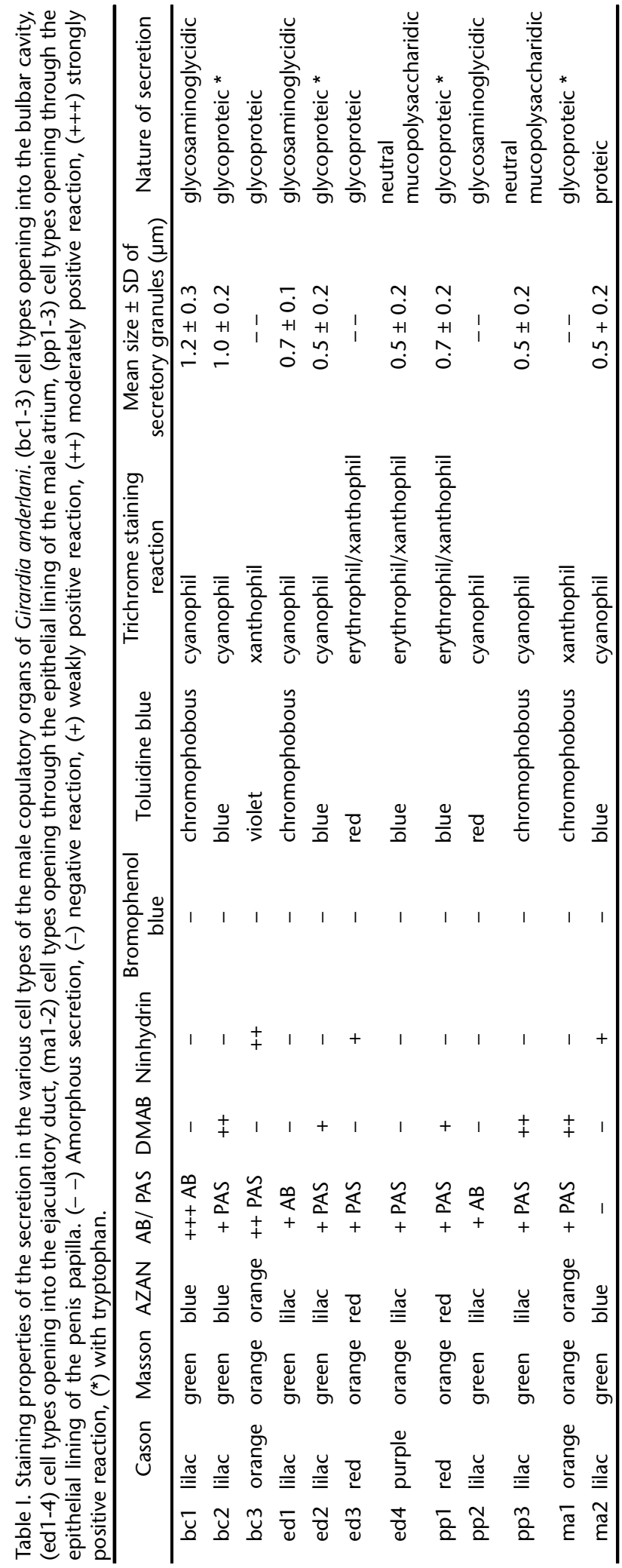

Revista Brasileira de Zoologia 25 (2): 263-268, June, 2008 

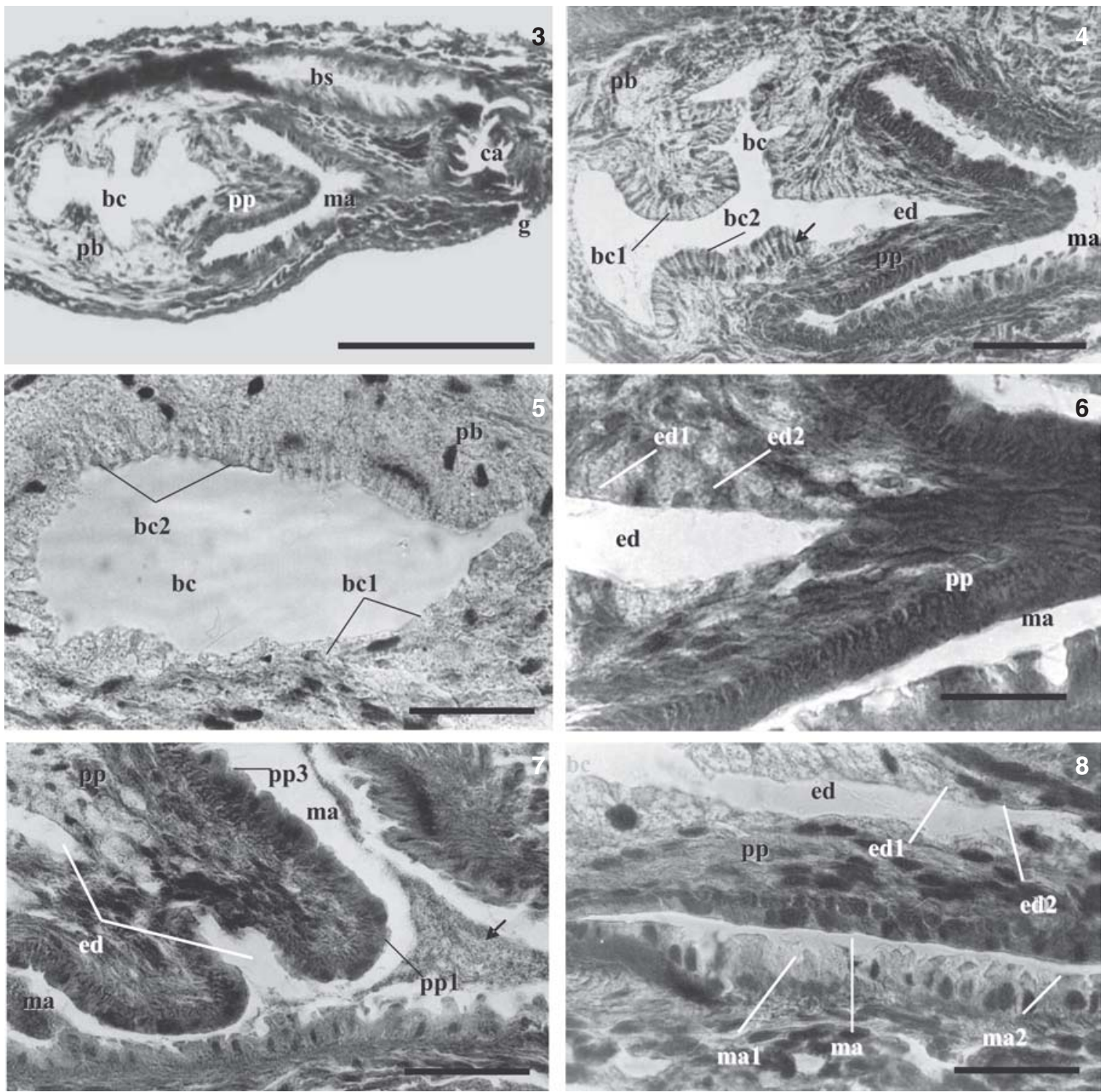

Figures 3-8. Girardia anderlani: (3) general view of the male copulatory organs, sagittal section stained with AZAN; (4) penis bulb (pb) and penis papilla (pp), sagittal section stained with AZAN, arrow indicates the lining epithelium of the bulbar cavity; (5) bulbar cavity with the openings of cell types bc1 and bc2. Sagittal section stained with toluidine blue; (6) detail of penis papilla and ejaculatory duct, sagittal section stained with toluidine blue; (7) tip of penis papilla and male atrium, sagittal section stained with toluidine blue, arrow indicates an ejaculate in the atrium; (8) detail of penis papilla and male atrium, sagittal section stained with toluidine blue. (bc) Bulbar cavity, (bc1) cell type bc1, (bc2) cell type bc2, (bs) bursal stalk, (ca) common atrium, (ed1) cell type ed1, (ed2) cell type ed2, (ma1) cell type ma1, (ma2) cell type ma2, (ed) ejaculatory duct, (g) gonopore, (ma) atrium, (pb) penis bulb, (pp) penis papilla, (pp1) cell type pp1, (pp3) cell type pp3. Scale bar: $50 \mu \mathrm{m}$.

The penis papilla is lined by columnar epithelium (Figs 1 and 6-8) that becomes cuboidal during copulation. Three types of secretory cells (pp1-3) open through this epithelium. Cell type pp1 has more openings at the tip of the penis papilla (Figs 2 and 7). Cell types pp1 and pp3 have fine secretory granules, erythrophilic or xanthophilic in pp1 and cyanophilic in pp3. Cell type pp2 has a cyanophilic amorphous secretion that stains in red with toluidine blue. Glycosaminoglycidic secretions from pp2, glycoproteic secretions with tryptophan from pp1 and neutral mucopolysaccharides from pp3 (Tab. I) enter the atrium

Revista Brasileira de Zoologia 25 (2): 263-268, June, 2008 
through the epithelium of the penis papilla.

Tall columnar epithelium lines the atrium. Irregular in height, this epithelium receives necks of two types of secretory cells (ma1-2) (Figs 2, 7 and 8). Ma1 has a xanthophilic amorphous secretion comprising glycoproteins with tryptophan; ma2 has a fine granular cyanophilic secretion containing protein (Tab. I).

\section{DISCUSSION}

More secretory cell types comprise the glands of the male copulatory apparatus of $G$. anderlani when compared to other, histologically examined, species of Dugesiidae, such as Girardia festae, G. bonaerensis, G. schubarti, and G. biapertura (MоRETTO 1996, Leal-Zanchet \& Hauser 1999, Souza \& Leal-Zanchet 2002). Secretory cells containing glycoproteic and glycosaminoglycidic secretions are also more abundant and are broadly distributed in the male copulatory organs of G. anderlani than in those of other Girardia species. However, the use of few histochemical reactions in some studies may raise difficulties in identification of cell types, especially if they are in an inactive physiological phase.

In G. schubarti and G. biapertura (Leal-Zanchet \& Hauser 1999, SOUZA \& LeAL-ZANChet 2002), in a resting state of reproduction, proteic secretions were discharged into the bulbar cavity. In G. bonaerensis, proteic secretions were identified in cells opening into the ejaculatory duct (Mоretro 1996). In G. anderlani, cells with exclusively proteic secretions open only into a more distal portion of the copulatory apparatus, through the epithelial lining of the atrium. An acetylaminopolysaccharidic secretion, identified in cells opening into the ejaculatory duct of $G$. schubarti, was not found in G. anderlani nor other species (MORETTO 1996, Souza \& LeaL-Zanchet 2002). Unfortunately, the lack of information during similar reproductive phases in other species makes interpretation difficult, since we are unable to make the appropriate comparisons.

Histological and histochemical examination of secretory cells will help identify functionally distinct regions of the reproductive apparatus that have no clear anatomical differences, as SOUZA \& LEAL-ZANCHET (2002) proposed when analyzing the secretory cells of the intrapenial ducts of G. biapertura. At a taxonomical level, improved understanding of tissue functions assists in the recognition of possible homologies (WINSOR 1998). Thus, histological and histochemical analysis of glands of reproductive organs may provide very important features for characterization of species (Sluys 1992, SouzA \& Leal-Zanchet 2002).

\section{ACKNOWLEDGEMENTS}

The authors thank Leigh Winsor and two anonymous referees for comments and suggestions on an early draft of the manuscript. The Universidade do Vale do Rio dos Sinos and the Fundação de Amparo à Pesquisa do Rio Grande do Sul are acknowledged for financial support. Thanks are also due to Welcy H. Santos for assistance with observation of the reproduction and fixation of the flatworms, as well as Letícia A. Guterres and Aline F. Centa for help with histological technique.

\section{LITERATURE CITED}

BennetT, H.S.; A.D. Wyrick \& J.H. Macneil . 1976. Science and art in preparing tissues embedded in plastic for light microscopy, with special reference to glycol methacrylate, glass knives and simple stains. Stain Technology 51 (2): 71-97.

FisChlsChweiger, W. 1990. Ultrastructure of the sperm duct and penis bulb of Dugesia tigrina (Platyhelminthes: Tricladida). Transactions of the American Microscopical Society 109: 141-151.

FISCHLSCHWEIGER, W. 1992. Ultrastructure of the penis papilla and antrum of Dugesia tigrina (Platyhelminthes: Tricladida). Transactions of the American Microscopical Society 111: 180-192.

FISCHLSCHWEIGER, W. 1994. Ultrastructure of the reproductive system of Cura foremanii (Platyhelminthes: Tricladida). Transactions of the American Microscopical Society 113 (1): 1-14.

Fischlschweiger, W. \& E. Clausnitzer. 1984. Bursa, bursa canal, and female antrum of Dugesia tigrina (Platyhelminthes: Tricladida). Zoomorphology 104: 386-395.

Hauser, J. 1952. Ausschaltung des Xylols in der histologischen Technik. Mikroskopie 7 (5-6): 208-211.

Kawakatsu, M.; J. Hauser; S.M.G. Friedrich; I. Oki; S. Tamura \& T. YAMOSHI. 1983. Morphological, karyological and taxonomic studies of freshwater planarians from South Brazil. IV. Dugesia anderlani sp. nov. (Turbellaria, Tricladida, Paludicola), a new species from São Leopoldo in Estado de Rio Grande do Sul. Annotationes Zoologicae Japanenses 56 (3): 196-208.

KaWAKatsu, M.; J. HAuser \& S.M.G. Friedrich. 1986. Morphological, karyological and taxonomic studies of freshwater planarians from South Brazil. VIII. Four Dugesia species (D. tigrina, D. schubarti, D. anderlani and D. arndti) collected from several localities in Estado de Rio Grande do Sul (Turbellaria, Tricladida, Paludicola). Bulletin of the Fuji Women's College, Serie 2, 24: 41-62.

Leal-Zanchet, A.M. \& J. Hauser. 1999. Penis glands of the dugesiid planarian Girardia schubarti (Platyhelminthes, Tricladida, Paludicola). Invertebrate Biology 118 (1): 35-41.

Moretto, H.A. 1996. La planaria chilena Dugesia sanchezi (Platyhelminthes: Turbellaria) y Dugesia bonaerensis sp. nov., planaria de la pampa húmeda de Buenos Aires, Argentina. Revista Chilena de História Natural 69: 213-230.

Pearse, A.G.E. 1968. Histochemistry: Theoretical and Applied. London, J. \& Churchil, vol. 1, 1517p.

Plattnert, N. 1975. Die chemische Fixierung biologischer Objekte für die Eletronenmikroskopie, p.39-40. In: G. SCHIMmel \& W. Vogell (Eds). Methodensammlung der Elektronenmikroskopie. Stuttgart, Wissenschaftliche Verlagsgesellschaft mbH, $135 \mathrm{p}$.

Revista Brasileira de Zoologia 25 (2): 263-268, June, 2008 
RomeIs, B. 1989. Mikroskopische Technik. München, Urban und Schwarzenberg. 750p.

Ruthmann, A. 1966. Methoden der Zellforschung. Stuttgart, Franckh'sche Verlagshandlung, p. 276-277.

SLuys, R. 1992. Synopsis of the freshwater triclads of the Caribbean (Platyhelminthes, Tricladida, Paludicola). Studies on the Natural History of the Caribbean Region 71: 1-23.

SLuYs, R. 1996. Reconsiderations of the species status of some South American planarians (Platyhelminthes, Tricladida, Paludicola). Proceedings of the Biological Society of Washington 109 (2): 229-235.
Souza, S.T. \& A.M. Leal-Zanchet. 2002. Histological and histochemical aspects of the penial glands of Girardia biapertura Sluys, 1997 (Platyhelminthes, Tricladida, Paludicola). Brazilian Journal of Biology 62 (3): 547-555.

Spurlock, B. O.; M.S. Skinner, \& A.A. Kattine. 1966. Simple rapid method for staining epoxi-embedded specimens for light microscopy with the polychromatic staining Paragon-1031. American Journal of Clinical Pathology 46: 252-258.

WINSOR, L. 1998. Aspects of taxonomy and functional histology in terrestrial flatworms (Tricladida: Terricola). Pedobiologia 42: 412-432.

Submitted: 16.IX.2007; Accepted: 10.VI.2008.

Editorial responsibility: Georgina Bond-Buckup 